\title{
IMPLEMENTASI UJI COBA MODUL-MODUL STATISTIKA BERBASIS SPREADSHEET UNTUK MAHASISWA JURUSAN AKUNTANSI POLITEKNIK
}

\author{
I Made Wijana \\ Jurusan Akuntansi, Politeknik Negeri Bali \\ imdwjn@gmail.com \\ Anak Agung Putri Suardani \\ Jurusan Akuntansi, Politeknik Negeri Bali \\ suardaniputri@yahoo.com
}

\section{Abstrak}

Tujuan penelitian ini untuk mengetahui hasil penilaian ahli terhadap draf modul-modul mata kuliah statistika berbasis spreadsheet untuk mahasiswa Jurusan Akuntansi Politeknik yang telah dihasilkan pada penelitian tahap sebelumnya (tahap pertama), untuk mengetahui bagian dari modul yang perlu direvisi, dan untuk mengetahui hasil uji coba terbatas dari draf modul-modul tersebut. Instrumen yang digunakan untuk penilaian terdiri atas lima aspek yaitu aspek pendahuluan, pembelajaran, isi, tugas, evaluasi, penilaian, dan rangkuman. Uji coba terbatas dilakukan pada dua kelompok mahasiswa Jurusan Akuntansi Politeknik Negeri Bali. Hasil penelitian menunjukkan penilaian ahli materi yaitu secara keseluruhan modul-modul dikategorikan baik dan tiap-tiap modul dari tujuh modul dikategorikan baik. Bagian dari modulmodul yang perlu direvisi terutama dalam hal kecukupan contoh yang disertakan pada aspek isi, tingkat kesulitan soal pada aspek tugas, evaluasi, penilaian, dan ketepatan dalam penjelasan materi teoritis pada aspek pembelajaran. Hasil uji coba secara keseluruhan modul-modul mata kuliah statistika ini memberikan nilai yang lebih baik secara signifikan bagi mahasiswa yang menggunakan modul dibandingkan mahasiswa yang tidak menggunakan modul. Semua modul memberikan nilai yang lebih baik secara signifikan kecuali modul Regresi dan Korelasi.

Kata kunci: Implementasi, Statistika, modul, berbasis spreadsheet

\section{TRIALS IMPLEMENTATION OF SPREADSHEET BASED STATISTICS COURSE MODULES FOR ACCOUNTING DEPARTMENT OF POLYTECHNIC STUDENTS}

\begin{abstract}
This research aims to know the results of the expert assessment on the module drafts that have been generated in the previous research stage (first stage), to determine which part of modules need to be revised, and to know the results of trials implementation of the module drafts. The instrument used for assesment covering five aspects: the introduction, learning, content, task,evaluation, assessment, and a summary. The trials implementation involving two groups of students from the Accounting Department Bali State Polytechnic. The results of the research show assessment of the expert is the overall modules are categorized good and all of the seven modules are also categorized good. Part of the modules need to be revised, especially in terms of examples adequacy, difficulty level of problems, and explanation accuracy in theoretical materials are included in the aspects of content, task/evaluation/assessment, and learning. The trials implementation of the overall statistical modules provide better results significantly for students who used the modules compared to students who did not use the modules. Every module provide better results signifcantly except on Regression and Correlation module.
\end{abstract}

Keywords: statistics, implementation, module, spreadsheet-based 


\section{PENDAHULUAN}

Sejumlah faktor yang menentukan keberhasilan proses belajar di sebuah perguruan tinggi di antaranya adalah keberadaan bahan ajar. Salah satu bentuk bahan ajar adalah modul. Menurut Nasution (Danuri, 2015, pp. 36-46) modul adalah suatu unit lengkap dan dapat berdiri sendiri serta terdiri atas suatu rangkaian kegiatan belajar yang disusun untuk membantu mahasiswa mencapai sejumlah tujuan yang dirumuskan secara khusus dan jelas. Selanjutnya, Purwanto (2007, p. 9) menyebutkan bahwa modul merupakan bahan ajar yang dirancang secara sistematis berdasarkan kurikulum tertentu serta memungkinkan dipelajari secara mandiri. Rizkiawan (2014, pp. 1-2) menyatakan penggunaan modul memiliki pengaruh tinggi sekali terhadap hasil belajar siswa. Hal serupa dari Ali, Ghazi, Khan, Hussain, \& Faitma (2010, p. 53) yang menyimpulkan bahwa pengajaran menggunakan modul lebih efektif dibandingkan metode tradisional khususnya untuk pelajaran Biologi karena siswa diberikan kesempatan belajar menurut level kemampuan dan kebutuhannya. Keberadaan modul dalam pembelajaran, diharapkan menjadi sumber belajar yang mampu mengatasi masalah keterbatasan waktu, sumber daya dan keberagaman kompetensi siswa seperti yang dinyatakan Rhosyida \& Jailani (2014, pp. 34-47).

Beberapa penelitian menunjukkan bahwa penggunaan modul dalam pembelajaran dapat meningkatkan prestasi belajar peserta didik. Mujiati (2013, pp. 390-397) menyimpulkan materi pada modul dapat membantu siswa mengembangkan kemampuan berpikir, pemecahan masalah, dan mengembangkan keterampilan intelektual. Kesimpulan serupa dikemukan Wicaksono, Widoretno, \& Nurmiyati (2015, pp. 60-66) bahwa penggunaan modul pada pembelajaran think pair share (berpikir mandiri, berpasangan, berbagi) berpengaruh signifikan terhadap pemahaman konsep peserta didik. Dengan demikian, diharapkan bisa meningkatkan prestasi siswa.

Untuk Mata Kuliah Statistika yang diberikan pada banyak program studi di perguruan tinggi, modul-modul yang digunakan bisa berbasiskan spreadsheet. Perangkat lunak spreadsheet digunakan secara luas termasuk dalam bidang pendidikan khususnya dalam pembelajaran. Mata kuliah yang materi pem- belajarannya berisi perhitungan-perhitungan tabel bisa menggunakan perangkat lunak spreadsheet seperti mata kuliah akuntansi, statistika dan lain-lain. Nash \& Quon (1996, pp. 1-2) menyatakan ada beberapa keuntungan penggunaan spreadsheets dalam pengajaran statistika antara lain: (1) pengajar bisa menyiapkan template terlebih dahulu agar bisa diikuti siswa untuk perhitungan tertentu; (2) pada spreadsheet, hasil kalkulasi bisa segera berubah ketika data diubah, (3) spreadsheet adalah alat komputasi umum yang baik sehingga sering diprogram untuk menghitung kalkulasi yang tidak standar; (4) paket program spreadsheet sekarang menyediakan perhitungan statistik yang umum, (5) paket program spreadsheet merupakan alat yang berguna untuk entri data, edit, dan manipulasi sebelum dimasukkan ke paket program statistik yang standar. Dalam pembelajaran Statistika, spreadsheet dapat digunakan untuk semua topik sebagai contoh regresi seperti digambarkan oleh Laviolette (1994, pp. 1-13). Martin \& College (2008, pp. 1-37) juga mengembangkan untuk pembelajaran regresi multipel menggunakan spreadsheet. Spreadsheet juga mendukung kegiatan belajar mengajar di bidang bisnis khususnya matematika bisnis seperti dikembangkan oleh May (2015, pp. 1-16). Demikian juga dengan Santoso (2008, pp. 110-116) yang menyimpulkan bahwa penggunaan spreadsheet dalam pengajaran Sistem Pengambilan Keputusan untuk mahasiswa peminatan Sistem Informasi atau ekuivalennya dianggap layak untuk dipertimbangkan oleh staf pengajar yang selama ini mengajarkan mata kuliah tersebut secara tradisional. Suatu dokumen spreadsheet untuk menghitung harga penawaran juga telah dibuat dan diusulkan sebagai salah satu bahan yang dapat digunakan dalam demonstrasi kelas atau tugas.

Walaupun keberadaan modul-modul penting dalam proses pembelajaran namun belum semua mata kuliah yang ada di perguruan tinggi dilengkapi dengan modul-modul termasuk mata kuliah Statistika di Jurusan Akuntansi Politeknik Negeri Bali (PNB). Sampai Tahun Akademik 2016 Program Studi Akuntansi Manajerial, Jurusan Akuntansi PNB belum mempunyai sumber belajar berupa modul-modul statistika. Mata kuliah Statistika yang merupakan bagian dari matematika secara umum dan mendukung mata 
kuliah yang lainnya mengandung materi yang penuh dengan rumus-rumus yang panjang. Banyak mahasiswa di perguruan tinggi khususnya mahasiswa Jurusan Akuntansi Politeknik yang kesulitan memahami dan melakukan perhitungan-perhitungan untuk mendapat hasil dari rumus-rumus tersebut. Untuk memudahkannya maka diperlukan tabel-tabel untuk mengelaborasi rumus-rumus panjang tersebut dan bisa dengan mudah diterapkan pada paket program spreadsheet.

Oleh karena itu, perlu dikembangkan modul-modul mata kuliah statistika berbasis spreadsheet yang inovatif dan diharapkan bisa diterapkan pada pembelajaran di Jurusan Akuntansi PNB maupun di perguruan tinggi vokasi lainnya melalui penelitian ini. Tahap pertama penelitian sudah berjalan dan menghasilkan draf modul-modul statistika berbasis spreadsheet yang sudah mendapat validasi awal. Tahap selanjutnya adalah penilaian atau validasi dari ahli materi sebelum dilakukan uji coba terbatas.

Berdasarkan latar belakang permasalahan tersebut, maka yang menjadi pokok permasalahan dalam penelitian ini adalah: (a) bagaimana hasil penilaian ahli terhadap draf modul-modul mata kuliah statistika berbasis spreadsheet, (b) apa saja yang perlu direvisi terhadap draf modul-modul mata kuliah statistika berbasis spreadsheet, dan (c) bagaimana hasil uji coba terbatas dan respon mahasiswa terhadap modul-modul mata kuliah statistika berbasis spreadsheet

Adapun tujuan yang ingin dicapai penelitian ini adalah: (a) mengetahui hasil penilaian ahli terhadap draf modul-modul mata kuliah statistika berbasis spreadsheet, (b) mengetahui yang perlu direvisi terhadap draf modul-modul mata kuliah statistika berbasis spreadsheet, dan (c) mengetahui hasil uji coba terbatas dan respon mahasiswa terhadap modul-modul mata kuliah statistika berbasis spreadsheeet untuk mahasiswa Jurusan Akuntansi Politeknik Negeri Bali.

\section{METODE PENELITIAN}

Penelitian ini merupakan tahap kedua dari pengembangan modul statistika berbasis spreadsheet untuk mahasiswa Jurusan Akuntansi Politeknik. Tahap pertama dengan tahapan analisis kurikulum, analisis kebutuhan dan validasi awal sudah terlaksana dengan hasil tujuh draf modul yang sudah mendapat validasi awal dengan judul modul: Data Statistik, Distribusi Frekuensi, Ukuran Pemusatan, Ukuran Dispersi, Regresi dan Korelasi, Time Series, dan Angka Indeks (Wijana \& Suardani, 2015, pp. 173-182). Pada tahap kedua ini, draf ke tujuh modul yang sudah mendapat validasi awal direvisi kemudian dinilai atau divalidasi oleh ahli materi. Penilaian atau validasi ahli materi diadopsi dari Sungkono (2016, pp. 1-16) yang menggunakan lima aspek penilaian yaitu aspek pendahuluan, pembelajaran, isi, tugas, evaluasi, penilaian, dan rangkuman. Setiap aspek penilaian terdiri atas beberapa item untuk diberikan skor dengan menggunakan skala Likert skala 5. Kemudian hasil penilaian pada setiap aspek dicari rata-rata skornya dan kategorinya. Kriteria kategori hasil penilaian yang digunakan mengacu kepada Sukardjo (Admadja \& Marpanaji, 2016, pp. 173-183) yaitu "Sangat Baik" apabila $X>4,08$, "Baik" apabila $3,36<\mathrm{X} \leq 4,08$, "Cukup" apabila 2,64 $<\mathrm{X} \leq 3,36$, "Kurang" apabila $1,92<\mathrm{X} \leq 2,64$, dan "Sangat Kurang" apabila $\mathrm{X} \leq 1,92$. Modul yang sudah divalidasi kemudian diuji coba secara terbatas pada dua kelompok kecil mahasiswa. Tahap ketiga adalah dengan melakukan uji coba lapangan dengan melibatkan lebih banyak mahasiswa. Langkah terakhir pada tahap ini adalah dengan membuat prototipe dari modul statistika berbasis spreadsheet.

Populasi penelitian adalah seluruh mahasiswa semester II program studi Diploma IV Akuntansi Manajerial, Jurusan Akuntansi, Politeknik Negeri Bali tahun akademik 2015/ 2016 sebanyak empat kelas atau sebanyak 100 orang. Dari empat kelas atau sebanyak 100 orang mahasiswa yang ada, diambil sampel menggunakan metode cluster dengan terlebih dahulu mengambil dua kelas secara acak. Selanjutnya, dari setiap kelas yang terpilih diambil 17 orang dijadikan sampel sebagai peserta uji coba secara terbatas sehingga banyak sampel seluruhnya menjadi 34 orang. Sampel dari kelas yang pertama disebut grup I tempat modul diuji cobakan sedangkan sampel dari kelas yang kedua disebut grup II tempat modul tidak diterapkan.

Data yang dikumpulkan berupa hasil tes evaluasi (nilai) pada setiap modul mengunakan skala 100. Data tersebut terlebih dahulu dianalisis secara deskriptif, dengan menggambarkan statistik (nilai rata-rata dan deviasi 
standar) dari setiap grup pada setiap modul. Selanjutnya, diuji beda nilai rata-rata pada setiap modul dan keseluruhan modul antara grup I dan grup II dengan menggunakan uji t. Kriteria bahwa mean nilai grup I lebih besar secara siginifikan dari mean nilai grup II apabila nilai $\mathrm{t}_{\text {Hitung }}$ lebih besar dari $\mathrm{t}_{\text {Tabel }}$ atau $\mathrm{t}_{(32,5 \%)}=1,70$.

\section{HASIL DAN PEMBAHASAN}

Dari hasil penilaian ahli materi, untuk modul-modul secara keseluruhan skor rataratanya 3,98 dengan skor tertinggi 4,20 untuk aspek Pendahuluan dan skor terendah 3,64 untuk aspek Rangkuman seperti dapat dilihat pada Tabel 1.

Tabel 1. Hasil Penilaian Ahli Materi Secara Keseluruhan

\begin{tabular}{llc}
\hline No & Aspek yang Dinilai & $\begin{array}{c}\text { Skor } \\
\text { rata-rata }\end{array}$ \\
\hline 1 & Pendahuluan & 4,20 \\
2 & Pembelajaran & 4,00 \\
3 & Isi & 4,16 \\
4 & Tugas, evaluasi, penilaian & 3,88 \\
5 & Rangkuman & 3,64 \\
Skor rata-rata keseluruhan & 3,98 \\
\hline
\end{tabular}

Dengan demikian, secara keseluruhan modul-modul statistika ini dikategorikan baik oleh ahli materi karena skor rata-ratanya lebih besar dari 3,36 dan lebih kecil dari atau sama dengan 4,08. Untuk aspek penilaian pertama yaitu Pendahuluan yang terdiri atas 5 item penilaian diberikan skor rata-rata 4,2 dengan skor tertinggi 5,0 dan skor terendah 3,1. Dengan demikian, secara keseluruhan untuk aspek Pendahuluan modul-modul statistika ini dikategorikan baik oleh ahli materi karena skor rata-ratanya lebih besar dari 3,36 dan lebih kecil dari atau sama dengan 4,08. Untuk aspek penilaian kedua yaitu Pembelajaran dengan 10 item penilaian diberikan skor ratarata 4,0 dengan skor tertinggi 5,0 dan skor terrendah 3,3. Dengan demikian, secara keseluruhan untuk aspek Pembelajaran modulmodul statistika ini dikategorikan baik oleh ahli materi karena skor rata-ratanya lebih besar dari 3,36 dan lebih kecil dari atau sama dengan 4,08. Untuk aspek penilaian ketiga yaitu Isi dengan 7 item penilaian diberikan skor rata-rata 4,2 dengan skor tertinggi 5,0 dan skor terrendah 3,0. Dengan demikian, secara keseluruhan untuk aspek Isi modulmodul statistika ini dikategorikan baik oleh ahli materi karena skor rata-ratanya lebih besar dari 3,36 dan lebih kecil dari atau sama dengan 4,08. Untuk aspek penilaian keempat yaitu Tugas, evaluasi, penilaian dengan 6 item penilaian diberikan skor rata-rata 3,9 dengan skor tertinggi 5,0 dan skor terrendah 3,0. Dengan demikian, secara keseluruhan untuk aspek Tugas, evaluasi, penilaian modul-modul statistika ini dikategorikan baik oleh ahli materi karena skor rata-ratanya lebih besar dari 3,36 dan lebih kecil dari atau sama dengan 4,08. Aspek penilaian kelima yaitu Rangkuman dengan 4 butir penilaian diberikan skor rata-rata 3,6 dengan skor tertinggi 5,0 dan skor terrendah 2,0. Dengan demikian, secara keseluruhan untuk aspek Rangkuman modul-modul statistika ini dikategorikan baik oleh ahli materi karena skor rata-ratanya lebih besar dari 3,36 dan lebih kecil dari atau sama dengan 4,08.

Dari hasil penilaian ahli materi berdasarkan modul-modul, skor rata-rata tertinggi diberikan ahli materi untuk modul I dengan judul Data Statistik dan skor rata-rata terendah untuk modul Regresi dan Korelasi seperti dapat dilihat pada Tabel 2. Berdasarkan informasi pada Tabel 2, semua modul dikategorikan baik oleh ahli materi karena semua skor rata-ratanya lebih besar dari 3,36 dan lebih kecil dari atau sama dengan 4,08

Tabel 2. Hasil Penilaian Ahli Materi Berdasarkan Modul

\begin{tabular}{clc}
\hline Modul & \multicolumn{1}{c}{ Judul } & $\begin{array}{c}\text { Skor Rata- } \\
\text { rata }\end{array}$ \\
\hline I & Data Statistik & 4,09 \\
II & Distribusi Frekuensi & 4,02 \\
III & Ukuran Pemusatan & 3,94 \\
IV & Ukuran Dispersi & 3,99 \\
V & Regresi dan Korelasi & 3,92 \\
VI & Time Series & 3,97 \\
VII & Angka Indeks & 3,94 \\
\hline
\end{tabular}

Sejalan dengan hasil penilaian ahli materi, cukup banyak saran perbaikan yang diberikan dengan rekapan seperti digambarkan pada Tabel 3. 
Tabel 3. Rekapitulasi Saran Perbaikan Berdasarkan Aspek-Aspek

\begin{tabular}{llc}
\hline No & Aspek yang Dinilai & $\begin{array}{c}\text { Banyak } \\
\text { Revisi }\end{array}$ \\
\hline 1 & Pendahuluan & 7 \\
2 & Pembelajaran & 15 \\
3 & Isi & 9 \\
4 & Tugas, evaluasi, penilaian & 8 \\
5 & Rangkuman & 15 \\
\hline
\end{tabular}

Berdasarkan Tabel 1 tentang hasil penilaian ahli materi secara keseluruhan dan Tabel 3 tentang rekapitulasi banyak saran perbaikan berdasarkan aspek-aspek, bisa dilihat terdapat hubungan antara keduanya yaitu aspek yang mendapat skor rata-rata tertinggi $(4,20)$ adalah aspek Pendahuluan mendapat saran perbaikan yang paling sedikit (7 buah) sedangkan aspek yang mendapat skor rata-rata terendah $(3,64)$ adalah Rangkuman mendapat saran perbaikan yang paling banyak (15 buah).

Saran perbaikan yang diberikan oleh ahli materi pada aspek Perdahuluan khususnya dalam hal berkaitan dengan modul yang lain yang prerekuisit pada modul II, modul III, sampai dengan modul VII. Perbaikan sudah dilakukan antara lain dengan menambahkan penyebutan modul Data Statistik pada kemampuan dasar yang harus dimiliki untuk mempelajari modul II (Distribusi Frekuensi). Pada modul III ditambahkan penyebutan modul Data Statistik dan Distribusi Frekuensi pada kemampuan dasar yang harus dimiliki untuk mempelajari modul III (Ukuran Pemusatan). Pada modul IV ditambahkan penyebutan modul Data Statistik, Distribusi Frekuensi, dan Ukuran Pemusatan pada kemampuan dasar yang harus dimiliki untuk mempelajari modul IV (Ukuran Dispersi). Pada modul V ditambahkan penyebutan modul Data Statistik, Ukuran Pemusatan, dan Ukuran Dispersi pada kemampuan dasar yang harus dimiliki untuk mempelajari modul $\mathrm{V}$ (Regresi dan Korelasi). Pada modul VI ditambahkan penyebutan modul Data Statistik, Ukuran Pemusatan, dan Ukuran Dispersi, Regresi dan Korelasi pada kemampuan dasar yang harus dimiliki untuk mempelajari modul VI (Time Series). Sedangkan, pada modul VII ditambahkan penyebutan modul Data Statistik dan Ukuran Pemusatan pada kemampuan dasar yang harus dimiliki untuk mempelajari modul VII (Angka Indeks).
Pada aspek Pembelajaran saran perbaikan yang diberikan oleh ahli materi, khususnya dalam hal kejelasan sasaran pengguna pada semua modul dan dalam hal ketepatan dalam penjelasan materi teoretis pada modul II, modul III, sampai dengan modul VI, dan dalam hal ketepatan dalam penjelasan materi praktis pada modul V, modul VI dan modul VII. Perbaikan sudah dilakukan antara lain dengan menambahkan pengguna modul ini adalah mahasiswa Jurusan Akuntansi Politeknik khususnya Jurusan Akuntansi Politeknik Negeri Bali.

Ahli materi juga menyarankan perbaikan pada aspek isi, khususnya dalam hal berkaitan dengan cakupan (keluasan dan kedalaman) isi materi pada modul I, modul IV, dan modul VII. Pada modul I disarankan perlunya tambahan contoh variabel acak pada populasi, pada modul IV perlu ditambahkan materi angka baku, dan pada modul VII perlu ditambahkan materi tentang indeks harga gabungan dengan rata-rata relatif. Saran lainnya pada aspek isi adalah berkaitan dengan item kejelasan dan kecukupan contoh yang disertakan pada modul I, modul II dan modul III. Pada modul I disarankan perlunya tambahan contoh contoh lebih aktual tentang jenis data, pada modul II perlu ditambahkan contoh distribusi frekuensi dengan tampilan satu angka di belakang koma, dan pada modul III perlu ditambahkan interpretasi pada semua contohcontoh ukuran letak.

Selanjutnya, pada aspek Tugas, evaluasi, penilaian saran perbaikan yang diberikan oleh ahli materi, khususnya dalam hal tingkat kesulitan soal pada modul III, modul VI dan modul VII dan dalam hal proporsi soal latihan/tes dengan isi materi pada modul I. Saran pada modul III agar ditambahkan soal yang lebih sulit demikian juga pada modul VI dan modul VII. Pada modul I juga perlu ditambahkan soal tentang pengantar statistika sesuai dengan isi modul.

Terakhir ,ahli materi juga menyarankan perbaikan pada aspek Rangkuman khususnya dalam hal kejelasan rangkuman modul (komprehensif) pada modul I, modul III, dan modul IV dan daftar pustaka pada semua modul. Pada modul I, modul III, dan modul IV disarankan perlunya rangkuman yang lebih rinci dan pada semua modul perlu ditambahkan daftar pustaka yang merupakan referensi dari modul-modul tersebut. 
Dengan menggunakan modul yang telah direvisi, uji coba terbatas dilakukan dengan hasil untuk modul I dengan judul "Data Statistik" adalah nilai rata-rata kelompok bermodul $\left(\bar{X}_{1}=80,47\right)$ lebih besar daripada nilai rata-rata kelompok tidak bermodul $\left(\bar{X}_{2}=74,35\right)$. Setelah dilakukan uji beda ratarata dengan uji $t$ diperoleh nilai $t_{\text {hitung }}=1,723$ lebih besar daripada $t_{\text {Tabel }}$ atau $t_{(32,5 \%)}=1,70$ artinya nilai rata-rata untuk modul I kelompok bermodul lebih tinggi secara signifikan daripada nilai rata-rata kelompok tidak bermodul.

Hasil uji coba terbatas selengkapnya untuk modul I sampai dengan modul VII dan keseluruhan ditampilkan pada Tabel 4 dan Tabel 5.

Tabel 4. Hasil Uji Coba Modul-Modul

\begin{tabular}{lllll}
\hline \multirow{2}{*}{ Modul } & \multicolumn{2}{c}{ Grup I } & \multicolumn{2}{c}{ Grup II } \\
\cline { 2 - 5 } & $\bar{X}_{1}$ & $\mathrm{~s}_{1}$ & $\bar{X}_{2}$ & $\mathrm{~s}_{2}$ \\
\hline I & 80,47 & 9,57 & 74,35 & 11,08 \\
II & 82,53 & 9,70 & 75,65 & 11,12 \\
III & 80,47 & 8,65 & 74,88 & 10,12 \\
IV & 81,06 & 12,41 & 74,12 & 11,24 \\
V & 84,76 & 14,49 & 80,82 & 12,86 \\
VI & 77,88 & 7,01 & 71,65 & 7,83 \\
VII & 82,00 & 9,70 & 75,41 & 8,54 \\
$\begin{array}{l}\text { Keselu- } \\
\text { ruhan }\end{array}$ & 81,31 & 8,77 & 75,27 & 8,16 \\
\hline
\end{tabular}

Tabel 5. Hasil Uji Coba Modul-Modul

\begin{tabular}{llll}
\hline Modul & $\mathrm{T}_{\text {hitung }}$ & $\mathrm{T}_{\text {tabel }}$ & Keterangan \\
\hline $\mathrm{I}$ & 1,72 & 1,70 & Signifikan \\
$\mathrm{II}$ & 1,92 & 1,70 & Signifikan \\
III & 1,73 & 1,70 & Signifikan \\
IV & 1,71 & 1,70 & Signifikan \\
V & 0,84 & 1,70 & Tidak Signifikan \\
VI & 2,45 & 1,70 & Signifikan \\
VII & 2,21 & 1,70 & Signifikan \\
$\begin{array}{l}\text { Keselu- } \\
\text { ruhan }\end{array}$ & 2,08 & 1,70 & Signifikan \\
\hline
\end{tabular}

Dari Tabel 4 bisa dilihat bahwa pada semua modul, grup I (kelompok bermodul) mendapat nilai rata-rata lebih besar daripada grup II (kelompok tidak bermodul) dan secara lebih jelas bisa dilihat pada Gambar 1.

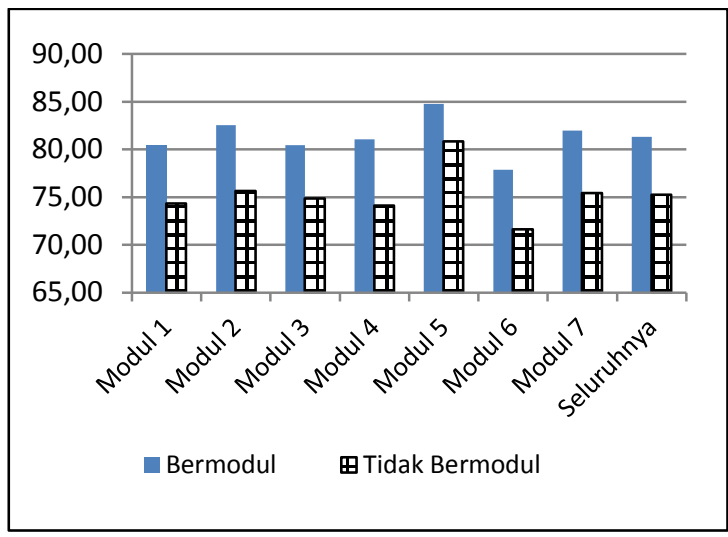

Gambar 1. Grafik Nilai Rata-

RataKelompok Bermodul danTidak Bermodul

Tabel 5 menunjukkan bahwa setelah dilakukan uji beda rata-rata dengan uji $t$ diperoleh nilai $t$ hitung yang lebih besar dari $\mathrm{t}_{\text {Tabel }}$ atau $\mathrm{t}_{(32,5 \%)}=1,70$ pada semua modul kecuali pada modul V. Artinya, nilai rata-rata grup I (kelompok bermodul) lebih besar secara signifikan daripada nilai rata-rata kelompok tidak bermodul kecuali pada modul $\mathrm{V}$ dan secara lebih jelas bisa dilihat pada Gambar 2.

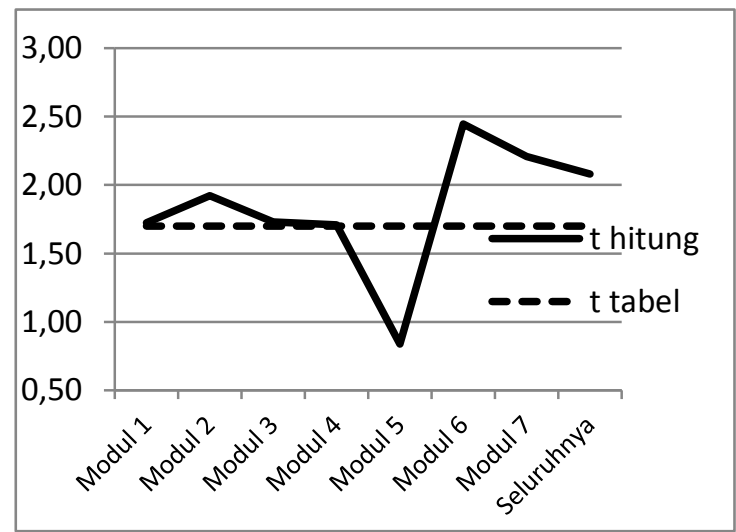

Gambar 2. Grafik Hasil Uji t

Hasil uji coba terbatas untuk keseluruhan modul, grup I (kelompok bermodul) mendapat rata-rata $\left(\bar{X}_{1}=81,31\right)$ lebih besar daripada nilai rata-rata kelompok tidak bermodul $\left(\bar{X}_{2}=75,27\right)$ seperti ditampilkan pada Tabel 4. Setelah dilakukan uji beda rata-rata dengan uji $\mathrm{t}$ diperoleh nilai $\mathrm{t}$ hitung $=2,08$ lebih besar daripada $t_{\text {Tabel }}$ atau $t_{(32,5 \%)}=1,70$ seperti ditampilkan pada Tabel 5. Artinya, nilai rata-rata untuk modul secara keseluruhan, kelompok bermodul lebih tinggi secara signifikan daripada nilai rata-rata kelompok tidak bermodul. Dengan demikian, bisa dikatakan modul- 
modul statistika berbasis spreadsheet ini bisa memberikan prestasi yang lebih baik secara terbatas pada kelompok mahasiswa Jurusan Akuntansi Politeknik Negeri Bali.

Perbedaan prestasi grup I dan grup II secara lebih jelas bisa dilihat dari sebaran nilainya seperti pada Tabel 6 , Tabel 7 , dan Gambar 3 dengan menggunakan kategori menurut Politeknik Negeri Bali (2013, pp. 1146).

Tabel 6. Sebaran Nilai Hasil Uji Coba Terbatas Grup I

\begin{tabular}{cccc}
\hline Kategori & Rentang & $\begin{array}{l}\text { Freku- } \\
\text { Ensi }\end{array}$ & $\%$ \\
\hline A & 81 ke atas & 8 & 47,1 \\
AB & $76-80$ & 3 & 17,6 \\
B & $66-75$ & 5 & 29,4 \\
BC & $61-65$ & 1 & 5,9 \\
C & $56-60$ & 0 & 0 \\
D & $41-55$ & 0 & 0 \\
E & 40 ke bawah & 0 & 0 \\
\multicolumn{2}{r}{ Jumlah } & 17 & 100 \\
\hline
\end{tabular}

Tabel 7. Sebaran Nilai Hasil Uji Coba Terbatas Grup II

\begin{tabular}{cccc}
\hline Kategori & Rentang & $\begin{array}{l}\text { Freku- } \\
\text { Ensi }\end{array}$ & $\%$ \\
\hline $\mathrm{A}$ & 81 ke atas & 4 & 23,5 \\
$\mathrm{AB}$ & $76-80$ & 2 & 11,8 \\
$\mathrm{~B}$ & $66-75$ & 8 & 47,1 \\
$\mathrm{BC}$ & $61-65$ & 3 & 17,6 \\
$\mathrm{C}$ & $56-60$ & 0 & 0 \\
$\mathrm{D}$ & $41-55$ & 0 & 0 \\
$\mathrm{E}$ & 40 ke bawah & 0 & 0 \\
\multicolumn{2}{c}{ Jumlah } & 17 & 100 \\
\hline
\end{tabular}

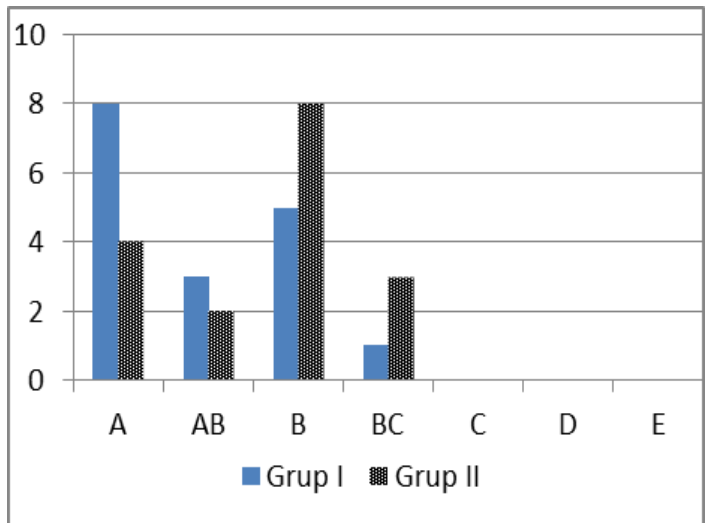

Gambar 3. Grafik Sebaran Nilai Uji Coba Terbatas Grup I dan Grup II
Selanjutnya dalam penelitian ini juga ditanyakan respon mahasiswa yang masuk grup I (kelompok bermodul) terhadap penggunaan modul statistika berbasis spreadsheet dengan hasil seperti pada pada Tabel 8, Tabel 9, dan Tabel 10.

Tabel 8. Respon Mahasiswa Bahwa Modul Berbasis Spreadsheet Mempermudah Belajar Statistika.

\begin{tabular}{ccc}
\hline Kategori & Frekuensi & $\%$ \\
\hline Sangat Setuju & 6 & 35,3 \\
Setuju & 11 & 64,7 \\
Cukup Setuju & 0 & 0 \\
Kurang Setuju & 0 & 0 \\
Tidak Setuju & 0 & 0 \\
Jumlah & 17 & 100 \\
\hline
\end{tabular}

Tabel 8 menunjukkan sebagaian besar mahasiswa di grup I $(64,7 \%)$ setuju bahwa modul berbasis spreadsheet mempermudah dalam belajar statistika. Selanjutnya dominan dari mereka $(58,8 \%)$ merasa bahwa penggunaan modul berbasis spreadsheet bisa menghemat waktu dalam belajar statistika seperti ditampilkan pada Tabel 9. Hal ini tentu mendukung harapan modul sebagai bahan ajar yang bisa mengatasi masalah keterbatasan waktu seperti diutarakan Rhosyida \& Jailani (2014, pp. 35-47).

Tabel 9. Respon Mahasiswa bahwa Modul Berbasis Spreadsheet bisa Menghemat Waktu dalam Belajar Statistika

\begin{tabular}{ccc}
\hline Kategori & Frekuensi & $\%$ \\
\hline Sangat Setuju & 6 & 35,3 \\
Setuju & 10 & 58,8 \\
Cukup Setuju & 1 & 5,9 \\
Kurang Setuju & 0 & 0 \\
Tidak Setuju & 0 & 0 \\
Jumlah & 17 & 100 \\
\hline
\end{tabular}

Penggunaan modul berbasis spreadsheet juga bisa membuat mahasiswa mandiri dalam belajar statistika seperti ditampilkan pada Tabel 10.

Tabel 10 menunjukkan paling banyak dari mahasiswa $(41,2 \%)$ merasa bahwa penggunaan modul berbasis spreadsheet bisa membuat mandiri dalam belajar statistika. Hal 
ini sejalan dengan pendapat Purwanto (2007, p. 9).

Tabel 10. Respon Mahasiswa Bahwa Modul Berbasis Spreadsheet Membuat Mahasiswa Mandiri Belajar Statistika.

\begin{tabular}{ccc}
\hline Kategori & Frekuensi & $\%$ \\
\hline Sangat Setuju & 3 & 17,6 \\
Setuju & 7 & 41,2 \\
Cukup Setuju & 6 & 35,3 \\
Kurang Setuju & 0 & 0 \\
Tidak Setuju & 1 & 5,9 \\
Jumlah & 17 & 100 \\
\hline
\end{tabular}

\section{SIMPULAN}

\section{Simpulan}

Berdasarkan hasil yang telah dicapai pada bab-bab sebelumnya maka dapat diambil simpulan sebagai berikut: (1) Hasil penilaian ahli adalah secara keseluruhan modul-modul dikategorikan baik dengan skor rata-rata 3,98 dan seluruh modul dari tujuh modul dikategorikan baik karena setiap modul dengan skor rata-ratanya lebih besar daripada 3,36 dan lebih kecil atau sama dengan 4,08, (2) Perbaikan/revisi yang masih diperlukan untuk meningkatkan kualitas modul-modul mata kuliah statistika ini adalah pada aspek pendahuluan khususnya dalam hal keterkaitan dengan modul yang lain yang prerekuisit, pada aspek pembelajaran khususnya dalam hal kejelasan sasaran pengguna, pada aspek isi khususnya dalam hal cakupan (keluasan dan kedalaman) isi materi, pada aspek tugas, evaluasi, penilaian khususnya dalam hal tingkat kesulitan soal, dan pada aspek rangkuman khususnya dalam hal kejelasan rangkuman serta daftar pustaka, dan (3) Hasil uji coba modul-modul mata kuliah statistika ini adalah secara keseluruhan modul-modul mata kuliah statistika ini memberikan nilai yang lebih baik secara signifikan bagi mahasiswa yang dijadikan sampel untuk menggunakan modul dibandingkan mahasiswa yang dijadikan sampel tidak menggunakan modul. Dari tujuh buah modul, semuanya memberikan nilai yang lebih baik secara signifikan bagi mahasiswa yang dijadikan sampel untuk menggunakan modul dibandingkan mahasiswa yang dijadikan sampel tidak menggunakan modul kecuali pada modul $\mathrm{V}$ yang hasilnya tidak signifikan. Respon mahasiswa yang menggunakan modul adalah sebagaian besar dari mereka setuju bahwa modul berbasis spreadsheet bisa mempermudah $(64,7 \%)$, lebih hemat waktu $(58,8 \%)$ dan membuat mandiri $(41,2 \%)$ dalam belajar statistika.

\section{Saran}

Berdasarkan simpulan tersebut maka dapat disarankan beberapa hal sebagai berikut: (1) Modul-modul statistika berbasis spreadsheet ini sudah diuji coba walaupun secara terbatas dengan hasil baik untuk membantu meningkatkan prestasi mahasiswa sehingga disarankan mahasiswa Jurusan Akuntansi Politeknik bisa menggunakannya, dan (2) dalam menggunakan modul-modul statistika berbasis spreadsheet ini mahasiswa Jurusan Akuntansi Politeknik hendaknya memperhatikan petunjuk penggunaan modul, memanfaatkan spreadsheet yang sudah disediakan dalam mengerjakan tugas-tugas serta berkonsultasi dengan dosen pengampu apabila menemukan kesulitan-kesulitan.

\section{DAFTAR PUSTAKA}

Admadja, I. P., \& Marpanaji, E. (2016). Pengembangan multimedia pembelajaran praktik individu instrumen pokok dasar siswa smk di bidang keahlian karawitan. Jurnal Pendidikan Vokasi, 6(2), 173-183. Retrieved from http://journal.uny.ac.id/index.php/jpv/ar ticle/view/8107/8014

Ali, R., Ghazi, S. R., Khan, M. S., Hussain, S., \& Faitma, Z. T. (2010). Effectiveness of modular teaching inbiology at secondary level. Asian Social Science, 6(9), 49-54.

Danuri. (2015). Pengembangan modul matematika 3 dengan pendekatan kontekstual untuk memfasilitasi pemahaman konsep dan kemandirian belajar mahasiswa PGSD. In Seminar Nasional Universitas PGRI Yogyakarta (pp. 36-46). Yogyakarta.

Laviolette, M. (1994). Linear regression: the computer as a teaching tool. Journal of Statistics Education, 2(2), 1-13. 
Martin, D., \& College, D. (2008). Spreadsheet tool for learning the multiple regression f-test, t-tests, and multicollinearity. Journal Of Statistics Education, 16(3), $1-37$.

May, T. (2015). Using spreadsheets to develop applied skills in a business math course: Student feedback and perceived learning. Spreasheets In Education (eJSiE), 8(3), 1-16.

Mujiati. (2013). Pengembangan modul bercirikan Work-Based learning untuk meningkatkan prestasi siswa SMK pada materi matematika keuangan. In $K N P M$ $V$ Himpunan Matematika Indonesia.

Nash, J. C., \& Quon, T. K. (1996). Issues in teaching statistical thinking with spreadsheets. Journal of Statistics Education, 4(1), 1-2.

Purwanto. (2007). Pengembangan modul. Jakarta: Departemen Pendidikan Nasional Pusat Teknologi Informasi dan Komunikasi Pendidikan.

Rhosyida, N., \& Jailani. (2014). pengembangan modul matematika smk bidang seni, kerajinan, dan pariwisata berbasis open-ended problem sebagai implementasi ktsp. Jurnal Riset Pendidikan Matematika, 1(1), 35-47. Retrieved from http://journal.uny.ac.id/index.php/jrpm/ article/view/2662/2215
Rizkiawan, E. M. (2014). Pengaruh penggunaan modul terhadap hasil belajar siswa pada kompetensi dasar mengidentifikasi sistem starter. Retrieved May 14, 2016, from http://repository.upi.edu/12961/2/S_TM _0906913_Abstract.pdf

Santoso, E. S. (2008). Pengunaan spreadsheet dalam pengajaran sistem pendukung keputusan. Jurnal Fasilkom, 6(1), 110116.

Sungkono. (2016). Pengembangan instrumen evaluasi media modul pembelajaran.

Wicaksono, A. R., Widoretno, S., \& Nurmiyati, N. (2015). Pengaruh penggunaan modul berbasis research pada pembelajaran think pair share dan group investigation terhadap pemahaman konsep dan kemampuan metakognisi peserta didik kelas x SMA Negeri 1 Boyolali tahun ajaran 2013/2014. Bioedukasi, 8(1), 60-66. Retrieved from http://jurnal.fkip.uns.ac.id/index.php/bi ologi/article/view/7249/5036

Wijana, I. M., \& Suardani, A. A. P. (2015). Pengembangan modul mata kuliah statistika berbasis spreadsheet untuk mahasiswa jurusan akuntansi politeknik (analisis kurikulum dan kebutuhan). Jurnal Teknodik, 19(2), 173-182. 